\title{
HUBUNGAN ANTARA PENERIMAAN DIRI DENGAN DEPRESI PADA PENDERITA DIABETES MELITUS (TIPE II)
}

\author{
Sofiyah \\ Fakultas Psikologi Universitas Mercu Buana Yogyakarta \\ sofiyah@gmail.com
}

\begin{abstract}
Abstrak
Penelitian ini bertujuan untuk mengetahui hubungan antara Penerimaan Diri dengan Depresi pada Penderita Diabetes Melitus. Hipotesis yang diajukan dalam penelitian ini adalah terdapat hubungan negatif antara Penerimaan Diri dengan Depresi pada Penderita Diabetes Mellitus. Semakin tinggi penerimaan diri, maka semakin rendah depresi pada penderita diabetes mellitus, demikian sebaliknya semakin rendah penerimaan diri, maka semakin tinggi depresi pada penderita diabetes mellitus. Subjek penelitian ini adalah penderita Diabetes Melitus sebanyak 51 orang dan tidak ditentukan umur. Alat pengumpulan data menggunakan skala yaitu Skala Penerimaan Diri dan Skala Depresi. Hasil analisis dengan uji korelasi product moment diperoleh $r_{\chi \gamma}$ sebesar $-0,283 \quad(p<0,05)$. Hal ini menunjukan adanya hubungan negatif yang sangat signifikan antara penerimaan diri dengan depresi pada penderita diabetes mellitus, hipotesis yang diajukan dalam penelitian ini dapat diterima. Koefisien determinasi $\left(\mathrm{R}^{2}\right)$ yang diperoleh $=0,080$, artinya penerimaan diri dalam penelitian ini mampu memberikan sumbangan sebesar $8,0 \%$ terhadap depresi pada penderita diabetes mellitus. Hal ini sekaligus menegaskan pengaruh variabel lain yang tidak diteliti dalam penelitian ini sebesar $92 \%$.
\end{abstract}

Kata kunci: penerimaan diri, depresi pada penderita diabetes mellitus

\section{RELATIONSHIP BETWEEN SELF-ACCEPTANCE AND DEPRESSION ON DIABETES MELLITUS PATIENTS (TYPE II)}

\author{
Sofiyah \\ Fakultas Psikologi Universitas Mercu Buana Yogyakarta \\ sofiyah@gmail.com
}

\begin{abstract}
This study intended to find out the relationship between Self Acceptance with Depression in Diabetes Mellitus Patients. The hypothesis proposed in this study is that there is a negative relationship between Self Acceptance with Depression in Diabetes Mellitus Patients. The higher the self-acceptance, the lower the depression level in people with diabetes mellitus, vice versa the lower the self-acceptance, the higher the depression level in people with diabetes mellitus. The subjects of this study were 51 people with Diabetes Mellitus and not determined by age. The data collection tool used was the scale of Self Acceptance and Depression. The result of analysis with product moment correlation test obtained $r_{x \gamma}-0,283(p<0,05)$. This showed a significant negative relationship between self-acceptance and depression in people with diabetes mellitus. Thus, the hypothesis proposed in this study is acceptable. The coefficient of determination $\left(\mathrm{R}^{2}\right)$ obtained $=$ 0,080 , it means that self acceptance in this research able to influence of $8,0 \%$ to depression of diabetes mellitus patients. This at once confirms the influence of other variables not examined in this study by $92 \%$.
\end{abstract}

Keywords: self acceptance, depression in diabetes mellitus patient 


\section{PENDAHULUAN}

Pada era globalisasi saat ini umumnya masih banyak gaya hidup masyarakat yang masih belum memahami tentang pentingnya kesehatan. Individu pada umumnya mengkonsumsi segala jenis makanan, seperti : makanan tinggi lemak dan kolesterol tanpa diimbangi dengan olahraga atau aktifitas fisik untuk membakar lemak dan gaya hidup yang salah, seperti : kebiasaan merokok dan minum-minuman keras ataupun mengkonsumsi narkoba yang semuanya itu dapat menimbulkan dampak yang buruk bagi kesehatan. Masalah kesehatan yang mungkin muncul antara lain timbulnya penyakit reumatik, diabetes mellitus, jantung, ginjal dan sebagainya (dalam Winarni, 2007).

Tjokroprawiro(1993) mendefinisikan penyakit degenerasi sebagai penurunan fungsi akibat dari penimbunan-penimbunan jaringan itu sendiri (degenerasi murni) dan atau akibat dari endapan-endapan bahan lain pada jaringan tersebut (infiltrasi). Diabetes melitus tergolong dalam penyakit degenerasi murni infiltrasi.

Menurut Suyono (1999) diabetes melitus adalah suatu kumpulan gejala yang timbul pada seseorang yang disebabkan oleh karena adanya peningkatan kadar gula (glukosa) darah akibat kekurangan insulin baik absolut maupun relatif. Kadar glukosa dalam darah orang normal/sehat berkisar 60$120 \mathrm{mg} / \mathrm{dl}$ dalam keadaan puasa, an di bawah 140mg/dl pada dua jam sesudah makan. Kadar glukosa dalam darah orang diabetes melitus sekitar $200 \mathrm{mg} / \mathrm{dl}$. Selama ini dikenal ada dua jenis diabetes mellitus dengan perbedaan yakni diabetes mellitus tipe I yang tergantung sepenuhnya pada insulin dan diabetes mellitus tipe II yang masih dapat dibantu dengan obat-obatan lain.

Diabetes melitus Tipe II dikenal sebagai penyakit gula yang tidak tergantung Insulin. Diabetes melitus tipe II ini berkembang ketika tubuh masih mampu menghasilkan insulin tetapi tidak cukup dalam pemenuhannya atau bisa juga disebabkan karena insulin yang dihasilkan mengalami resistansi insulin dimana insulin tidak bekerja secara maksimal (Admin, 2011).

Menurut Soegondo (dalam Wijayanti, 2002) komplikasi diabetes melitus terjadi pada semua organ dalam tubuh yang dialiri pembuluh darah kecil dan besar dengan penyebab kematian: 50\% akibat penyakit jantung koroner dan 30\% akibat gagal ginjal. Selain kematian, diabetes melitus juga menyebabkan kecacatan. Lebih lanjut dijelaskan bahwa $30 \%$ penderita diabetes melitus mengalami kebutaan akibat komplikasi retinopati dan $10 \%$ harus menjalani amputasi tungkai kaki.

Hasil penelitian Engum dkk (2005) mengungkapkan bahwa prevalensi depresi secara signifikan lebih tinggi pada subjek yang menderita diabetes mellitus baik diabetes tipe I maupun tipe II dibandingkan populasi yang tidak menderita diabetes mellitus. Hal yang sama juga dikemukakan dari hasil penelitian Anderson; Gavard dkk; Knoel dkk (dalam www.wfmh.org) bahwa penderita diabetes memiliki dua kali kemungkinan mengalami depresi 
dibandingkan dengan individu yang tidak mengalami depresi.

Depresi merupakan suatu keadaan abnormal pada seseorang yang ditunjukkan oleh gejala-gejala seperti suasana hati yang murung, sikap pesimistis, perasaan kehilangan dan kosong, serta kehilangan spontanitas dan tanda-tanda perkembangan yang khusus, misalnya hilang selera makan, gangguan tidur dan hilangnya libido serta kelelahan (Beck, 1985).

Depresi memiliki beberapa gejala, La Haye (1998) mengemukakan gejala-gejala depresi ada 2 antara lain adalah: Gejala umum (fisik) yang berupa kelakuan aneh pada waktu tidur, kelesuan apatis, omong kosong, hilangnya nafsu makan, kehilangan nafsu seks dan penyakit-penyakit fisik yang seperti lemah, sakit kepala, sesak nafas, berdebar-debar, susah buang air besar dan berkeringat, sedangkan gejala emosional, pemusuhan, sifat lekas marah, kecemasan, rasa takut dan khawatir serta kehilangan harapan.

Lestari (dalam Anima, 2002), selain masalah luka dan komplikasi, penderita diabetes mellitus tipe II juga mengeluhkan pola makan. Agar dapat mengendalikan kadar gula darah, penderita diabetes mellitus harus rajin dan memeriksakan kadar gula darah serta disiplin minum obat sebagaimana yang ditentukan dokter. Perubahan gaya hidup berupa diet, olah raga dan minum obat seumur hidup merupakan proses yang tidak mudah karena untuk menjalankannya membutuhkan niat dan tekat yang kuat, selain itu juga dibutuhkan dukungan dari keluarga. Akan tetapi tidak sedikit dijumpai penderita diabetes mellitus yang mengalami depresi walaupun sudah mendapat dukungan dari keluarga.

Diabetes mellitus tidak bisa disembuhkan tetapi penderita bisa hidup dengan normal, untuk mencapai hidup normal penderita diabetes mellitus harus melakukan pengelolaan dengan baik. Pengelolaan dengan baik diperlukan kondisi psikologis yang baik untuk menghilangkan keluhan dan mempertahankan rasa nyaman dan sehat. Namun penderita diabetes mellitus merasa terganggu dengan keadaannya sehingga sebagian penderita mengalami depresi (Waspadji, 1999).

Beck (1985) menjelaskan bahwa depresi dapat dikenali melalui klasifikasi terhadap simptom- simptom emosional, kognitif, motivasional, fisik dan vegetatif. Symptom emosional meliputi kesedihan, suasana hati yang buruk, kesepian. Simptom kognitif seperti rendahnya penilaian terhadap diri sendiri, menolak bantuan orang lain, sulit mengambil keputusan. Simptom motivasional meliputi menurunnya atau hilangnya motivasi untuk melakukan aktivitas sederhana dalam kehidupan sehari-hari. Selanjutnya fisik dan vegetatif meliputi gangguan tidur, gangguan makan, hilangnya libido atau nafsu seksual dan mudah merasa lelah.

Penerimaan diri merupakan kemampuan untuk mengesampingkan kekurangan dan kesalahan, rasa malu yang merusak dan kecemasan yang ekstrim atau luar biasa. Individu yang dapat menerima 
dirinya sendiri, mampu menerima sifat manusiawi dengan segala kekurangan dan dengan segala yang tidak sesuai dengan cita-cita idealnya, serta puas akan keadaan dan sifat sebagaimana adanya (Maslow, 1994).

Ciri-ciri individu dengan penerimaan diri menurut Berger (dalam Kenneth, 1973) adalah perilaku didasarkan pada standar dan nilai dirinya sendiri bukan dari orang lain, individu memiliki keyakinan akan kemampuannya untuk menghadapi kehidupan, individu menerima tanggung jawab atas perilakunya dan menerima konsekuensi dari perilakunya, individu menerima pujian atau kritikan secara objektif.

Menurut kerangka kerja humanistik (Nevid dkk, 2005) bahwa orang menjadi depresi saat seseorang tidak dapat mengisi keberadaannya dengan makna. Berdasarkan kerangka kerja humanistik ini maka dapat dikatakan bahwa ketika perilaku individu didasarkan pada standar dan nilai dirinya sendiri akan mampu menemukan makna hidup dan selanjutnya akan tidak mudah mengalami depresi. Berdasarkan uraian

permasalahan tersebut, peneliti ingin mengetahui apakah ada hubungan antara penerimaan diri dengan depresi pada penderita diabetes mellitus tipe II. Penelitian ini bertujuan untuk mengetahui hubungan antara penerimaan diri dengan depresi pada penderita diabetes mellitus tipe II.

\section{METODE}

Variabel tergantung dalam penelitian ini adalah depresi, sedanglan variabel bebas adalah penerimaan diri. Depresi adalah gangguan psikologis pada individu yang mengakibatkan hilangnya motivasi untuk melakukan aktivitas sederhana dalam kehidupan sehari-hari (Beck, 1985). Depresi diungkap dengan BDI yang disusun oleh Retnowati (1990) berdasarkan gejala-gejala depresi yaitu sebagai berikut; (a) kesedihan, (b) pesimis, (c) perasaan gagal, (d) ketidakpuasan, (e) perasaan bersalah, (f) perasaan dihukum, (g) rasa tidak suka terhadap diri sendiri, (h) menyalahkan diri sendiri, (i) ide bunuh diri, (j) menangis, (k) iritabilitas, (l) menarik diri dari hubungan sosial, (m) ketidakmampuan mengambil keputusan, (n) perubahan citra tubuh, (o) keterlambatan dalam bekerja, (p) gangguan tidur, (q) kelelahan, (r) hilangnya nafsu makan, (s) hilangnya berat badan, (t) prokupasi somatik, (u) hilangnya libido.

Penerimaan diri merupakan sikap yang pada dasarnya merasa puas degan dirinya sendiri., kualitas- kualitas dan bakat sendiri, dan pengakuan atas keterbatasan diri sendiri. Tinggi rendahnya penerimaan diri subjek diperoleh melalui Skala Penerimaan Diri yang menunjukkan aspek-aspek penerimaan diri dari Berger (dalam Kenneth, 1973), yaitu: (a) Perilaku didasarkan pada standar dan nilai dirinya sendiri (internal) bukan dari orang lain (ekternal), (b) Memiliki keyakinan bahwa dirinya mampu mengahadapi kehidupan, (c) Menerima tanggung jawab atas perilakunya dan menerima konsekuensi dari perilakunya, (d) Menerima pujian atau kritikan secara objektif, 
(e) Tidak mencoba untuk menyangkal atau menyimpangkan perasaan, motif-motif, keterbatasan- keterbatasan atau kemampuankemampuannya yang ada dalam dirinya tetapi justru menerima semua hal tersebut tanpa dengan penghukuman diri, (f) Menganggap dirinya berharga sebagai manusia yang sederajat dengan orang lain, $(\mathrm{g})$ Tidak berfikir orang lain akan menolak dirinya baik ada alasan untuk menolak ataupun tidak ada alasan untuk menolaknya, (h) Tidak menganggap dirinya sendiri sebagai orang yang sangat berbeda dari yang lainnya atau menganggap dirinya orang yang tidak normal, (i) Tidak malu atau tidak terlalu sadar diri.

Dalam penelitian ini menggunakan subjek yang sudah didiagnosis menderita penyakit diabetes mellitus. Subjek dalam penelitian yaitu 51 penderita. Terdiri dari 20 pasien RSU PKU Muhammadiyah yang awat inap, 13 pasien RSU PKU Muhammadiyah yang berobat jalan, 18 subjek di luar rumah sakit.

Skala yang digunakan dalam penelitian ini adalah dengan menggunakan skala Beck Depression Inventory (BDI). Beck Depression Inventory yang terdiri dari 21 indikator depresi memiliki rentang penilaian atau skor dari 0 sampai 3. Masing-masing karakteristik ini menggambarkan manifestasi depresi dan terdiri dari 4-6 butir pernyataan. Pernyataan ini disusun bertingkat yang merefleksikan keadaan simtom- simtom depresi dari netral sampai terberat dengan nilai berkisar dari 13. Hasil perhitungan uji validitas menunjukkan semua aitem (yang berjumlah
21) dalam skala BDI dinyatakan valid, koefisien validitas dari Retnowati (1990) sebesar 0,234-0,610 dan diperoleh koefisien reliabilitas sebesar 0,833. Berarti BDI cukup reliable dan valid untuk digunakan dalam penelitian.

Skala penerimaan diri yang digunakan dalam penelitian ini adalah skala dengan tipe pilihan. Model skala yang digunakan mengacu pada model skala Likert dengan 4 kategori jawaban. Dalam pemilihan jawaban terdapat empat kategori yaitu SS (Sangat Sesuai), S (Sesuai), TS (Tidak Sesuai) dan STS (Sangat Tidak Sesuai). Cara pemberian skor untuk butir favourable yaitu pada jawaban SS diberi nilai 4; $\mathrm{S}$ diberi nilai 3; TS diberi nilai 2; dan STS diberi nilai 1. Sebaliknya, untuk butir unfavourable jawaban SS diberi nilai 1; $\mathrm{S}$ diberi nilai 2 ; TS diberi nilai 3; dan STS diberi nilai 4. Skor yang tinggi menunjukkan semakin tinggi penerimaan diri dan skor yang rendah menunjukkan semakin rendah penerimaan diri (Azwar, 1999). Berdasarkan hasil seleksi aitem skala dapat dipilih aitem-aitem yang memiliki koefisien validitas $\geq 0,300$ sebagai aitem valid atau memuaskan, sedangkan aitem yang memiliki koefisien validitas dibawah 0,300 dinyatakan gugur dan tidak digunakan dalam penelitian ini (Azwar, 1997). Uji validitas skala harga diri dalam penelitian ini sebanyak 52 aitem yang terdiri dari 25 aitem favourable dan 27 aitem unfavourable. Hasil uji validitas menunjukkan bahwa dari 52 aitem Skala Penerimaan Diri terdapat 11 aitem yang gugur. Sehingga dinyatakan 41 aitem 
dianggap valid dengan koefisien validitas aitem berkisar antara 0,321 sampai dengan 0,641 dan koefisen reliabilitas $\alpha$ sebesar 0,915 . Dalam penelitian ini data yang diperoleh akan dianalisis dengan menggunakan teknik korelasi product moment dari Karl Pearson.

\section{HASIL DAN PEMBAHASAN}

Hasil uji normalitas kedua variabel menunjukkan distribusi normal. Data variabel depresi menunjukkan nilai $\mathrm{KS}-\mathrm{Z}=0,093$ dengan taraf signifikansi sebesar 0,200 $(p>0,05)$, dan data variabel penerimaan diri menunjukkan nilai KS-Z $=0,093$ dengan taraf signifikansi sebesar $0,200(p>0,05)$. Hasil uji linearitas antara variabel depresi dengan variabel penerimaan diri menunjukkan nilai koefisien linier $\mathrm{F}$ sebesar 4.407 dengan taraf signifikansi sebesar $0,047 \quad(\mathrm{p}>0,05)$. Hal tersebut berarti kedua variabel memiliki hubungan yang linier.

Hasil uji hipotesis dengan menggunakan teknik korelasi product moment menunjukkan $\mathrm{r}_{\mathrm{xy}}$ sebesar - 0,283 dengan signifikansi $0,044(\mathrm{p}>0,05)$, artinya terdapat hubungan negative yang signifikan antara penerimaan diri dengan depresi. Analisis tambahan dalam penelitian ini menggunakan independent $t$ test. Perbedaan depresi berdasarkan usia memperoleh hasil $\mathrm{F}=2,911$ dengan signifikansi $0,094(\mathrm{p}>0,05)$ dan uji $\mathrm{t}=-1,610$, perbedaan depresi berdasarkan lama menderita memperoleh hasil $\mathrm{F}=1,555$ dengan signifikansi $0,320(\mathrm{p}>0,05)$ dan $t=1,005$, sedangkan perbedaan depresi berdasarkan jenis kelamin memperoleh hasil
$F=0,836$ dengan signifikansi $0,365(p>0,05)$ dan $\mathrm{t}=0,223$.

Berdasarkan hasil analisis data dapat dinyatakan bahwa terdapat hubungan negatif yang signifikan antara penerimaan diri dengan depresi pada penderita diabetes mellitus dengan korelasi $r_{x \gamma}$ sebesar $-0,283$ $(p<0,05)$. Hal tersebut berarti hipotesis yang menyatakan bahwa ada hubungan negatif antara penerimaan diri dengan depresi pada penderita diabetes mellitus diterima.

Hasil analisisis data tersebut yang dilakukan oleh Sukmaningrum (2001) dengan judul hubungan antara penerimaan diri dengan derajat depresi DM di RSPAD Gatot Subroto dan RS Hasan Sadikin. Hasil penelitian ini juga mendukung riset serupa yang dilakukan Anggarani (2007), bahwa ada hubungan negatif dan signifikan antara penerimaan diri dengan depresi pada remaja penyandang cacat fisik.

Nugroho (2003) juga menyatakan bahwa ketiadaan penerimaan diri akan menyebabkan penderita diabetes melitus merasa tersisihkan, tidak berharga, dan akhirnya akan terisolasi dari lingkungan. Kondisi ini akan menyebabkan penderita diabetes melitus mudah mengalami depresi. Hal ini menunjukkan apabila subjek mempunyai penerimaan diri yang tinggi, akan tampak dari keyakinan dan kemampuan subjek menghadapi kehidupan. Subjek mengalami penurunan motivasi untuk melakukan kegiatan sehari-hari, tetapi subjek masih memiliki rasa optimis untuk sembuh. Subjek juga masih memiliki pemikiran positif terhadap diri sendiri, karena subjek 
merasa masih banyak orang lain yang memperhatikan dan mendukung dirinya selama menjalani pengobatan. Selain itu meskipun terkadang subjek merasa sedih mengalami kelainan dalam bentuk tubuhnya, subjek tetap tidak malu dengan keadaan dirinya. Segala kekurangan yang dimiliki subjek masih dapat diterima, karena subjek memiliki keyakinan bahwa dirinya masih memiliki kelebihan yang lain untuk dikembangkan, orang lain masih memperhatikannya sehingga dapat mencegah timbulya depresi.

Menurut aspek-aspek penerimaan diri dari Berger (dalam Kenneth, 1973) maka penderita Diabetes mellitus yang menjadi responden penelitian ini secara umum memiliki penerimaan diri yang baik, memiliki toleransi terhadap frustasi atau kejadian- kejadian yang menjengkelkan, dan toleransi terhadap kelemahan- kelemahan dirinya tanpa harus menjadi sedih dan marah. Individu ini dapat menerima dirinya sebagai seseorang manusia yang memiliki kelebihan dan kelemahan. Jadi, penderita diabetes mellitus yang mampu menerima dirinya adalah individu yang dapat menerima kekurangan dirinya sebagaimana dirinya mampu menerima kelebihannya sehingga tidak mengalami depresi.

Hjelle (1992) mengemukakan bahwa seseorang yang memiliki penerimaan diri mempunyai gambaran positif terhadap dirinya dan dapat bertahan dalam kegagalan atau kepedihan serta dapat mengatasi keadaan emosionalnya, seperti: depresi, marah dan rasa bersalah.
Koefisien determinasi sebesar 0,080 memberikan sumbangan penerimaan diri terhadap depresi sebesar $8 \%$ dan $92 \%$ dipengaruhi oleh faktor lain yang tidak dilibatkan dalam penelitian ini. Variabel tersebut dapat berasal dari internal maupun eksternal individu, antara lain faktor biologis, faktor tingkatan kehidupan, konsep diri yang negatif, rendahnya harga diri dan penolakan.

Hasil uji perbedaan dengan Anava dan Uji-t menunjukkan bahwa tidak ada perbedaan depresi pada penderita diabetes mellitus berdasarkan usia, lama menderita dan jenis kelamin. Tidak adanya perbedaan depresi berdasarkan jenis kelamin tidak sesuai dengan pendapat Prawitasari dan Kahn (Renny, 2003) yang menyatakan bahwa kepribadian perempuan lebih emosional, sensitive dan kestrabilan emosi yang kurang akan mengakibatkan perempuan lebih depresif daripada laki-laki.

\section{KESIMPULAN}

Berdasarkan hasil penelitian ini dapat disimpulkan bahwa ada hubungan negative antara penerimaan diri dengan depresi pada penderita diabetes mellitus (tipe II).

\section{DAFTAR PUSTAKA}

Admin. 2011. Diabetes Melitus Tipe 2. http://www.diabetesmelitus.co mli.com/tipe-2.html. Diakses tanggal 21 juni 2011.

Anggarani, R. A. 2007. Hubungan Antara Penerimaan Diri dan Depresi Pada Remaja Penyandang Cacat Fisik Di Panti Rehabilitasi Sosial Bina Daska 
(PRSBD) Suryatama Bangil. www. Karya-ilmiah.um.ac.id/index.php/BK Psikologi/article/view/4095.

Azwar, S. 1997. Validitas dan Reliabilitas. Yogyakarta: Pustaka Pelajar.

Beck, A. T. 1985. Depression: Causes \& Treatmen. Philadelpia: University of pensylvania press.

Calhoun \& Accocella. 1990. Psikologi Tentang Penyesuaian dan Hubungan Kemanusiaan (Terjemahan). Edisi ke-3. Semarang: IKIP Semarang.

Hayati, N, 2002. Hubungan antara Lama Menjalakan Masa Hukuman dengan Kondisi Stress Narapidana di dalamn Rumah Tahanan Pajangan Bantul. Skripsi (tidak diterbitkan). Yogyakarta: Fakultas Psikologi Universitas Wangsa Manggala.

Hjelle, L. A., \& Ziegler, D. J. 1992. Personality Theories (3 Edition). Singapore: McGraw- Hill,Inc.

Kenneth. L. D. 1973. Self-Acceptance and Leader Effectivenss. Journal Of Extansion. Texas A \& M University.

La Haye, T. 1998. Depresi, Upaya dan Cara Mengatasinya. Semarang: Dahar Prize.

Lestari, B. S., Askandar, T., Fonzo,. Meller,. Subagyo, A., Golden, M.P., \& Karp, M. 2002.

Diabetes Melitus Tergantung Insulin (DMTI): Aspek Psikologik Penderita dan Keluarga. Anima, Indonesia Psychological Journal. Vol. 17. No. 2, 161-169.

Maslow, A. H. 1994. Mativasi \& Kepribadian 2: Teori Motivasi dengan Pendekatan Hlerarki Kebutuhan Manusia. Jakarta: PT. Pustaka Inaman Press.

Nevid, J. S., Spencer, A., Rathus., Beverly, G. 2005. Psikologi Abnormal. Edisi
Kelima Jilid 1. PT. Gelora Aksara Pratama: Penerbit Erlangga.

Obsorme, G. G. 1992. Seni Mengasihi Diri Sendiri. (Alih Bahasa: A. Widyamartaya). Cetakan ke-2. Yogyakarta. Kanisius.

Nugroho, P. R. 2003. Hubungan Antara Penerimaan Diri Dengan Depresi Pasca Operasi Pada Penderita Kanker Payudara. $\quad$ Skripsi. Yogyakarta: Universitas Wangsa Manggala.

Renny, E. S. 2003. Dukungan Sosial dan Depresi Narapidana di LP Kelas II A Wirogunan. Skripsi (tidak diterbitkan).Yogyakarta: Fakultas Psikologis Universitas Wangsa Manggala.

Retnowati, S. 1990. Terapi Kognitif dan Terapi Perilaku pada penenganan Gangguan Depresi. Tesis (tidak Diterbitkan). Yogyakarta: Pasca Sarjana Fakultas Psikologi Universitas Gadjah Mada.

Setyawat, E. A. 2002. Hubungan Antara Penerimaan Diri dengan Kepercayaan Diri Pada Pegawai Negeri Sipil dan Bukan Pegawai Negeri Sipil. Skripsi. Yogyakarta: Universitas Wangsa Manggala.

Sukmaningrum, S. S. 2001. Pegangan Penatalaksanaan Nutrisi Pasien: Nutrisi pada Diabetes Mellitus. Jakarta: Penghimpunan Dokter Gizi Medik Indonesia.

Suyono, S. 1999. Penatalaksanaan Diabetes Melitus Terpadu. Fakultas Kedokteran Universitas Indonesia. Jakarta: CV. Aksara Buana.

Tjokroprawiro. A. 1993. Diabetes Mellitus di Dalam Masyarakat Indonesia. Balai Penelitian Kesehatan,21, (4), 42-62.

Waspadji, S. 1999. Diabetes Melitus: Mekanisme Dasar Dan Pengelolahanya yang Rasional. Fakultas Kedokteran Universitas Indonesia. Jakarta: CV. Aksara Buana. 
Wijayanti, A. 2002. Hubungan

Kebermaknaan Hidup Dengan Kecemasan Terhadap Kematian Pada Penderita Diabetes Melitus. Skripsi. Yogyakarta: Fakultas Psikologi Universitas Wangsa Manggala.

Wilkinson, G. 1992. Depresi. Jakarta: Arcan. www.wfmh.org.The World Federation For Mental Health. 